\title{
Education System Reforms in an Unstable Political Situation: The Case of Serbia in the First Decade of the 21st Century
}

IVAN Ivić ${ }^{1}$ AND ANA PeŠIKAN ${ }^{\star 2}$

$\approx$ In the present paper, education reform in the Republic of Serbia since 2000 is presented. The focus is on two major reform waves: $2000-2003$ and 2004-2005. We analyse why these broad educational interventions failed. After 2005, there was a lull in the reform process, a period with no major changes (2005-2010). A new phase of improving education policy in Serbia commenced with the adoption of Trends in the Development and Upgrading of the Quality of Education and Upbringing 2010-2020 (2010) and the conception and proposal of the Strategy of Education Development in Serbia to $2020+$ (2012). The basic innovations in approach and conception in the new "epoch" is outlined.

Keywords: Education policy, Education reform, Serbia, Strategy of education development 


\section{Sistemske reforme na področju vzgoje in izobraževanja $\mathrm{v}$ politično nestabilnem času: Primer Srbije v prvem desetletju 21. stoletja}

IVAn Ivić In ANA PeŠIKan*

$\propto \mathrm{V}$ prispevku so predstavljene reforme na področju vzgoje in izobraževanja v Republiki Srbiji od leta 2000 naprej. V ospredju sta dva večja reformna vala: 2000-2003 in 2004-2005. Analizirani so razlogi, zakaj ta posega $\mathrm{v}$ izobraževanje nista bila uspešna. Po tem je sledilo obdobje, v katerem ni bilo večjih sprememb (2005-2010). Leta 2010 je sledilo novo obdobje $\mathrm{v}$ prizadevanjih za izboljšanje edukacijskih politik v Srbiji - sprejeti so bili Trendi za razvoj in izboljšanje kakovosti v vzgoji in izobraževanju 2010-2020 (2010) ter koncept in predlog Strategije razvoja izobraževanja v Srbiji do $2020+(2012)$. Poudarjene so temeljne novosti pristopa in koncepta novega obdobja.

Ključne besede: edukacijske politike, reforme na področju izobraževanja, Srbija, strategija razvoja izobraževanja 


\section{Introduction}

In October 2000, huge political changes took place in the Republic of Serbia. Essentially, these changes initiated processes that were very similar to the processes in other ex-socialist countries in regard to transition processes in economic, social and political life. In the period between 2000 and 2005, many changes occurred in the field of education. Due to political instability and the change of government, many radical changes, declarations of intended changes and actual implementation of changes with various political connotations occurred during this period.

In the following text, an analysis of education reform endeavours at the beginning of 21st century in Serbia is presented. In the last decade, two relevant reform waves can be recognised: the first, the changes in the period just after the country's major political changes, was in 2000 , while the second wave is represented by the changes in the period 2004-05. In the present text, the main characteristics of these two waves will be outlined along with the reasons for their success or failure in practice. The third, qualitatively new "wave" is the conception and realisation of the proposal of the Strategy of Education Development in Serbia to $2020+(2012)$ and the activities that preceded it.

\section{Education reform steps: Major characteristics of the changes introduced in 2001-2003}

As noted above, the transition ("reform") of the education system in Serbia began after the political changes that took place in October 2000 - the "October Democratic Revolution". This "revolution" initiated a transition process (economic, social, political) very similar to the transition processes in other exsocialist countries. The climate for introducing changes in the education system was therefore favourable. The political changes came about as a result of joint actions of a galvanised citizenry, the atmosphere in the country was positive, and the reforms were much awaited. The new democratic government created at the beginning of 2001 declared itself to be "radically reformist" (Ivić, 2005).

The field of education was already distinguished by great strengths and potential for positive changes.

- $\quad$ Since the mid 1990s, significant numbers of teachers and other education staff had been participating in numerous in-service training programmes. Almost all of these training programmes were realised with the help of international donors.

- Most of these programmes were oriented towards the democratisation 
of the education system and schools. Some programmes attempted to achieve this goal through the content of the training (civic education, child rights programmes), but all of them did so through the introduction of the methods used during the training (interactive/active methods), resulting in the mobilisation of teachers and creating a readiness for the expected changes.

There were, however, a certain number of drawbacks:

- The political parties that took power lacked guiding principles for the education reform. As a result, the Ministry of Education and Sport (MES) had a dual responsibility: firstly, to define its strategy and, secondly, to implement the reforms. This gives a clear picture of the overall context in which the theoretical framework for reforms was contextualised, and of the practical changes that were implemented.

- Consequent analysis of MES documents from that period (e.g. 2002, 2004) did not allow for easy identification of the general concept on which the reforms were based.

The concept was declaratively and broadly based on "quality education for all", "reconstruction of the education system", "modernisation", "Europeanisation", etc. Knezevic, the Minister of Education at the time, exhorted that "those who partook in the creation of the new education policies" are certain that their efforts will be sustainable because "...their idea of modern European education has already survived all of the turbulence in this region" (MES, 2004, p. 9). Apparently, the reforms were based on the introduction of "modern European education" into one specific region of Europe (Serbia). The idea of "modern European education" is not very clear and requires further explanation. Although there are education systems of individual EU member states, there is no single model of "European education". Post factum analysis of what the MES actually did leaves us with the impression that there really was not a single, clear and coherent idea of what "modern European education" meant. Clearly, the reform appeared to be an ad hoc compilation of separate measures borrowed from the education systems of other European countries. For example, why would it be more "European" to divide elementary school into 3 three-year cycles, instead of 2 four-year cycles, with a "zero" (Kindergarten) grade, or to change the duration of high school education to three instead of four years?

The declared "European" orientation meant two things. Firstly, it was clearly a "top-down" reform, which, first and foremost, meant that the reformists had an idea about what kind of education system they wanted and they 
built the reform around this idea. Secondly, just like the education reforms in many other countries in transition in this region (except Slovenia, perhaps), the reform was obviously conceptualised in the spirit of an "Etic" rather than an "Emic" approach. Any system in a given culture can be changed only by following the inner logic of the system itself, its characteristics and potentials, focusing on the spontaneous growth of change, using the strengths within system (Emic approach). The second approach is to try to introduce the changes that fit some theoretical model or to take an outside example as a starting point and to impose changes on the system (Etic approach). To borrow these terms from cultural anthropology is quite appropriate in the present context, since the education system of every country greatly depends upon the cultural characteristics of that country. What happened in Serbia during the initial reforms clearly indicates that the reforms were conducted following the second, Etic approach (Ivić, 2001). This claim can be supported by the fact that within the policy documents of the previous Ministry we could not find any serious assessment of the existing problems of the time (problems that still exist) in Serbian education. Such an assessment could serve as a basis for finding solutions and resources in the existing system. Instead, the solutions were conceptualised theoretically and then tried out within the system.

The attempt to reform education during 2001-2003 was quite comprehensive. All previously attempted reforms of the education system in Serbia focused almost exclusively on changing school programmes (i.e., the content of what is being taught), but the concept of the 2001-2003 reforms was very different. The reform concept (not the results, however) addressed all relevant aspects of education, almost at the same time: the structure of the education system, the system of financing, the management of the entire system, the information system, school programmes, textbooks, the professional development of education staff, the mechanisms for monitoring and evaluating student achievement, the development of educational institutions, the system of lifelong learning, etc. Changes in this period included:

- Legislature (the adoption of a general law on education, i.e., the "Umbrella 1 Law");

- Building new independent professional institutions (The National Council for Education, The Centre for Curricula and Textbooks, The Centre for Professional Teacher Development, The Centre for Evaluation);

- The structure of the education system (primary education length - nine instead of eight years divided into three cycles; secondary school - three instead of four years);

- Curricula that are more flexible (individual schools could create part of 
the curriculum by themselves);

- VET (adaptation of the structure of the VET to changes in the economic structure).

These changes took place in the spirit of an "etic approach", and were close to the concept of top-down reforms. However, most of the changes were implemented near the end of the three-year mandate of the MES, and were therefore unlikely to be sustainable.

The concept of the reforms developed by the MES (in power 2001-2003) was operationalised in the Law on the Foundations of Education (referred to here as the "Umbrella 1 Law"), adopted by Parliament in June 2003. The content of this "Umbrella 1 Law" is evident from particular solutions presented in following section.

\section{Main components of the 2001-2003 education reforms}

The main characteristics of the 2001-03 education reforms and the impacts of these reforms can be best seen if we summarise the theoretical ideas and planned activities behind them and then look at the concrete achievements, which will, inevitably, once again confirm that the reform was comprised of many individual measures without a clearly defined and coherent conceptual framework.

a. Legislature. During the 2001-03 reforms, there were very few changes in the legal regulative related to education. In 2002, some necessary amendments to the existing Law on Primary and Secondary Education were adopted: the appointment process for school principals was modified, school board membership was changed so as to increase the number of parents and representatives of the local community, the control function of school inspections was reduced, and a professional advancement system for teachers was introduced (upon which salary increases and bonuses were to be contingent - an important motivating factor to instigate changes in behaviour). The most important achievement, however, was the adoption by Parliament of the Law on the Foundations of the Education System (an "umbrella" school act) in June 2003. This law incorporated many of the reform ideas that will be discussed later. Unfortunately, due to political reasons, it was passed hastily, without serious discussion and debate.

The implementation of this "Umbrella Law" began rapidly, on 1 September, without allowing enough time for schools to prepare. The existing Laws on Primary and Secondary Education and the Law on Textbooks were still in 
effect, containing clauses that were at least partially in contradiction with the new "Umbrella Law", while new Laws on Preschool Education and Adult Education were not passed, and the same textbooks remained in use - all contributing to great difficulties in the implementation of the new "Umbrella Law".

b. Independent Institutions. In order to effectively implement the reforms, it was necessary to create certain independent expert institutions that had not previously existed in Serbia. The "Umbrella Law" provided the possibility of creating several such institutions: The Centre for School Programmes and Textbooks, The Centre for the Professional Development of Teachers, The Centre for Vocational Educational Training (VET), The Centre for Evaluation, The National Council for Education, The National Council for VET, etc.

The National Council for Education, as the highest independent body on the national level with a responsibility to direct and define long-term education policy, was instituted at the very end of the 2001-03 Ministry's mandate. Its members were appointed by the same Ministry and all of the policy documents were already adopted by the Ministry.

The Centre for Evaluation, funded by a World Bank loan, began its work at the end of 2003. Its personnel were well trained, and they developed the necessary organisational and management procedures, conducted a national assessment of student achievement at the end of the 3 rd grade, and analysed the results (some of these activities took place after the political power change, i.e., after the fall of the 2001-03 Ministry from power). The Centre, now called the Institute for Evaluation of Quality in Education, continues its work.

The Centre for School Programmes and Textbooks and the Centre for the Professional Development of Teachers also continued their work under the new Ministry, with changed work organisation and somewhat different responsibilities and competencies.

c. System of Financing. Many changes were planned (decentralisation of financing and a new formula for financing individual schools based on payment per student with some correction mechanisms), but none of these changes were ever realised. The salaries of teachers increased. If the index (100\%) represents the average salary in January 2002, then salaries in December 2002 did, indeed, increase to around $175 \%$; however, this was not part of the education reform, but rather reflected an overall state-wide real increase in salaries in the public sector.

In the state budget, there were no supplementary financial sources to support the education reform, as there was no interest in doing so, not in the 
government or the Parliament, nor amongst the general public. The percentage of GDP allocated to education during the 2001-03 reforms was even lower than previously: in $1997-4.5 \%$, in $1998-3.79 \%$, and in $2002-3.2 \%$, and $2003-3.4 \%$ (Ivić, 2005). The only sources of financing the costs of the reform were a modest loan from the World Bank and individual donations received from the governments of other countries and international organisations.

d. Decentralisation of the Management System. This was one part of the loudly propagated $3 \mathrm{D}$ formula: depoliticisation, decentralisation and democratisation of the system. According to the new law, instead of having the exclusive power to appoint school principals, the Ministry now only had the jurisdiction to approve the choice made by school boards, which were now comprised of three school representatives, three parents and three local community representatives. Part of the WB loan was used for decentralisation. Even under the new "Umbrella Law", the Ministry retained key decision-making power - political parties running the local municipalities appointed the majority of school board members from their echelons (local community representatives as well as school representatives) therefore, it can hardly be assumed that any real depoliticisation and democratisation occurred. The audit results of how the portion of the WB credit was used for decentralisation are still awaited.

e. Education System. The structure of the education system was changed significantly: one more grade was added to compulsory primary education, and this new 9-year primary education system (ISCED 1 and 2 ) was then sectioned into three 3-year cycles. Furthermore, it was suggested that the duration of all secondary schools be reduced to three years (including lyceums or college prep schools). These major structural changes were never the subject of public discussion, and the reformers themselves were never able to present any meaningful arguments related to the benefits and effects of such major perturbations in the education system.

The possible consequences (financial, organisational, and personnelrelated) of such major changes were never considered: what to do with the surplus of teachers in high schools when three-year schools came into existence (before they had been four-year schools); how to handle the deficit of teachers in primary education when it was extended by another year; the surplus or shortage of physical space in schools; the possible increase in drop-out rates in primary education caused by the extension of compulsory education and the introduction of more demanding general programmes; the problems that would befall rural elementary schools; and similar headache issues. 
None of these enforced changes proved sustainable. The new Ministry that assumed power in 2004 immediately annulled all of these initiatives because they were unachievable within the planned time frame, and their consequences were unpredictable.

f. Curricular Reform. In this domain, too, some major changes were planned. New courses were introduced, exclusively for political reasons (one of the two - either Civic Education or Religious Education - became a compulsory course). The second foreign language was introduced as early as in the 1st grade - again, without any serious assessment of the capacities and abilities of schools to respond to such a demand (e.g., the availability of properly trained teachers). Furthermore, a number of elective courses were introduced - hastily and without enough time for schools to prepare, and without assessment of schools' capacities to realise them. Instead of separate courses for various science disciplines (Physics, Biology and Chemistry courses) a new Science course was introduced at the beginning of the second primary school cycle, with total disregard for the need of teachers to suddenly prepare to switch to teaching this new subject (for which they had not been trained at their faculties). The number of instructional hours for maths, chemistry and physical sciences was reduced.

Furthermore, a major change was planned in relation to the structure of curricula. Instead of prescribed and mandatory curricular content for each subject, only a framework was to be defined, allowing each individual school, directed just by these general guidelines, to design their own Operational Programmes. School programmes were not defined by the mandatory curricular content, but rather by learning outcomes defined through benchmark goals and objectives. Only some required courses were mandatory - schools were given the freedom to independently design and implement about $10-30 \%$ of the programmes during the second and third primary education cycle. The curricular documents aimed at the first generation of students under the "reformed" education system (1st and 7 th grades) were presented for public discussion in April, and were to be implemented by September (it was assumed that the new textbooks could be printed and teachers trained within a four month period).

A portion of the WB loan was used for the so-called School Development Project (SDP), through which individual schools were funded for projects relevant to the issues prioritised by the schools themselves and related to local community needs. Schools had problems defining their SDP even after completing preparatory SDP training for several reasons: initiative behaviour had not been practiced for 50 years in Serbia (due to the one-party system and a highly centralised decision- making processes in the country), the overall 
climate was not supportive, and there was a mismatch between schools taking responsibility for their own development and the quality of work and real support for doing so in the MES and the local community.

The Ministry of Education that assumed power in 2004 annulled the majority of these initiatives, especially those aimed at changing the structure of school programmes. School programmes are again defined through curricular content and are compulsory - they must be implemented by all schools in Serbia. Our opinion is that the originally envisioned changes were neither well conceptualised nor properly implemented. Moreover, they were implemented hastily, and it was impossible to predict the results they would achieve once implemented.

The idea of defining the standards of knowledge for certain academic areas (benchmark educational outcomes) has not been entirely rejected, and the process of defining the learning standards to be achieved at the end of primary education in various academic areas is currently underway. The majority of financial resources allocated to the Evaluation Project by the WB loan has been rerouted towards achieving this goal.

The Science course was eliminated, and the study of Physics, Chemistry, and Biology as separate courses was reinstated. Some elective courses were retained, but their number and instructional time were decreased. Instructional time for mathematics and sciences was returned to the level prior to the reform (because it was not possible both to reach the intended outcomes and to match the programmes and outcomes).

SDP continued because it was considered to be important for the development of school autonomy and the professional growth of educators. However, the amount of financial assistance to each individual school for this project was very modest from the very beginning.

g. School Textbooks. The new Law on School Textbooks was not passed (the old law gave exclusive rights and a complete monopoly to just one public publisher). The 2001-03 Ministry requested that quality standards for school textbooks be developed, but even before this task was completed the Ministry liberalised and opened up the textbook market, allowing schools/teachers to independently select textbooks for various subjects. However, this was done without any accompanying legal regulative, and could have resulted in corruption and in a decrease in the quality of school textbooks.

Quality standards for textbooks were completed in November 2004, but they were not "officially" adopted - they had to be adopted by The National Council for Education that was not yet operational. The new Ministry that was instituted in 2004 prepared a draft of the Law on Textbooks. However, 
since new school programmes are still prepared in a rush, textbooks are being published in the same manner - hastily. The accreditation of school textbooks remains a weak point due to inappropriate standards that the Institute for Improvement in Education implemented as a criterion (adopted by the National Council for Education in 2010).

h. Professional Development of Teachers. The 2001-03 education reform profited greatly from the knowledge and skills of teachers and other school personnel who had been acquiring new skills since the mid 1990s, long before the "reform" began, through attending various training seminars and workshops. During the 2001-03 reform, in-service teacher training continued even more intensely and frequently. This was possible due to generous donations from foreign donors (UNICEF, WB, the governments of Switzerland, Austria, Norway and Greece, the Soros Fund, and others).

After the "Umbrella Law" was passed, the Centre for the Professional Development of Teachers was instituted (with Swiss support). Similar regional centres were envisioned (but not defined their mutual relationship) and a number of in-service programmes for additional teacher training received accreditation from the Ministry. Two catalogues listing these accredited programmes were printed, the second of which contained 335 in-service programmes (MES, 2003a), so that schools could select those they were interested in. However, only about 20 of the programmes were put into practice; most of them were pure improvisation (prepared just for the Catalog). The new catalogues (2010/11, 2011/12) have the same structural problems as the old ones; the number of programmes has increased to 840 , of which only $0.5 \%$ are evaluated in some way, with only one programme being subjected to international evaluation (Pešikan, Antić, \& Marinković, 2010a, 2010b).

The question of who should finance in-service teacher training was never resolved; the Ministry assumed that municipalities should provide funding, but they simply had no means to do so. Work commenced on by-law regulations defining the details of the professional advancement process and upgrading criteria for teachers (the teacher career ladder) based on the attendance of training seminars mentioned in the "Umbrella Law", but this work was never completed and the system of teacher professional advancement never took root.

The Centre for the Professional Development of Teachers continues its work as part of the Institute for Improvement in Education. The Rulebook for Accreditation of Programmes for Professional Development was being compiled. It emphasized professional development directed at specific subject content areas, rather than teaching methods. The problem of financing these 
programmes remains; neither the Ministry nor local municipalities have inservice teacher training on their budget line. The professional advancement system for teachers has not been implemented because the problem of financing the increase of salaries for teachers who fulfil the professional advancement requirements has not been solved yet.

i. The Information System in Education. With WB financial support, activities aimed at the creation of a single unified information education network was initiated (enabling the Ministry, creating regional centres, electronically linking every individual school with the regional and central level, delivery of hardware). Creation of a unified information network has never been completed. The main problems, especially data gathering and assuring the quality of data, have remained up to the present day (Pešikan, 2012). The precise results produced in this area with the moneys from the WB loan have never been publicly announced. There are still great overlaps and disparities in data gathering methods and analysis schemes between the Statistical Office of the Republic of Serbia and the MES. Information is not accessible to the general public and reporting on the collected data is irregular.

j. Vocational Education and Training (VET). The Strategy for Vocational Training Development was created during the 2001-03 reforms. Only in this area was some inter-sector cooperation and collaboration noticeable (the Ministry of Social Affairs, the Chamber of Commerce, the Ministry of the Economy, National Employment Agencies, Labour Unions, etc.). A detailed assessment of the VET schools network was made and an analysis of the effects of the predicted changes on the country's economy was conducted jointly by all of the above-mentioned stakeholders. Consequently, some new vocational training programmes were introduced and teachers were trained to teach them. Support and collaboration was realised with the GTZ, ETF, EU CARDS programme, etc. The Strategy for Vocational Training Development was adopted at the highest level - the government of the Republic of Serbia. The Ministry of Education that took power in 2004 continued all activities on the reconstruction and modernisation of VET programs.

k. Early Childhood Care and Education. In this area, only a couple of strategic policy papers were created. The Law on Preschool Education, complementary to the new "Umbrella Law", was created in 2010. Accreditation criteria and procedures have not been adopted yet and the quality of preschool education control mechanisms has never been defined. Since 1992, it has been possible 
to open a private preschool institution legally, but there are no accreditation and quality control mechanisms. No concrete measures related to changing the current state of affairs in early preschool education have ever been adopted. Moreover, a decrease in preschool enrolment has been noted lately.

1. Adult Education/Lifelong Education. In this domain, a number of strategic and policy papers were created and a survey of the current situation was conducted. However, no new legal regulative was passed until 2012. Since January 2012, the Draft Law on Adult Education has been in parliamentary procedure. Adult schools are rare, and no concrete measures related to changing the current state of affairs in adult education have ever been adopted.

m. Education of Children with Disabilities. Some strategic and policy papers were created but no necessary legal regulative was passed. The system of segregated, dilapidating special schools with a watered-down school curriculum and ill-prepared staff still exists in Serbia, parallel to the general education system. A small number of children attend these schools. UNICEF and Save the Children have piloted some inclusive projects, but with limited success. The Guide for Work with Children with Disabilities was created. The Ministry of Social Affairs created a Protocol for the Assessment of the Special Needs of Children with Disabilities (replacing the so-called Categorisation Guidelines). In 2009, new inclusive education commenced in practice, but without sufficient preparation of all participants in the process and with numerous obstacles that had not been solved in advance (Rado, 2009; Rado \& Lazetic, 2010).

\section{Education reform steps: Changes introduced in 2004-2005}

After the parliamentary elections, a new government was created from the opposing political option (spring 2004). This government supported certain changes in the area of education, but these were not nearly as radical as the previous changes. The new Ministry of Education and Sports did not explicitly conceptualise their own vision of the education system; instead, it seemed to be focused on certain concrete, direct, practical measures, and it only sporadically issued statements by high-ranking Ministry officials. One of the measures the new Ministry undertook was to annul and abolish some of the innovations introduced by the previous Ministry.

One of the most significant changes introduced by the new Ministry was the Amendments and Additions to the Law on the Foundations of the 
Education System in Serbia (the new "Umbrella Law" is referred to here as the "Umbrella 2 Law"). The narrative of the new "Umbrella 2 Law" indicates some of the general ideas guiding the new Ministry. The Ministry stood for "...systematic, rational and incremental changes to the educational system...", “...constant assessment, analysis and modification of the implemented school programmes and curricula" (MES, 2005, p. 25). The Ministry clearly articulated that "...one of the main goals of the child's education and socialisation should be to develop an awareness about one's own national being and statehood, to cherish and appreciate Serbian culture and traditions, as well as traditions and cultures of other ethnic and national minorities, and to develop an interest in and openness towards the cultures of various other traditional religions" (MES, 2005, p. 26). It is clear that the new Ministry held a significantly less radical and more conservative orientation in reforming education.

The "Umbrella 2 Law" annulled all of the structural changes in the education system introduced previously, since they caused too much turbulence within the system. Structural changes in curricula (curricula conceived as general and specific outcomes and objectives, more flexible curricula, some freedom for schools to partially build their own curricula) were annulled. Traditional school programmes were reinstated - serious and academically exigent curricular content was returned, complemented by learning standards defined for each course at the end of the learning process.

The new Ministry instituted a greater quantity of general curricular content as required and mandatory for all students. Another important change introduced was the National Council for Education as autonomous professional body in charge of making all education policy decisions (members were selected by the Parliament). It should be pointed out, however, that some political criteria did affect, albeit slightly, the selection of members of this important body. The new Ministry also introduced some changes in the organisation, responsibilities and jurisdiction of the independent professional institutions formed by the previous Ministry (there are now two professional institutions the Institute for the Improvement of Education and the Institute for the Evaluation of Quality in Education).

In May/June 2005, the Ministry of Education posted two important policy documents on its website (there was no public discussion about these documents), the first entitled "The National Strategy for Education from 2005 to 2010" and the second "Strategy of the Ministry of Education and Sport for the Period from 2005 to 2010 ". It is difficult to comment on these documents. The first document is too brief, and issues for discussion remain scant as there is a lack of information. The second document (124 pages) is difficult to comment 
on because the issues discussed lack clarity and the development of education in Serbia is neither well discussed nor sufficiently elaborated. With the exception of VET, very little is clarified.

If this document is viewed as a strategy for the development/improvement of education in Serbia, then several things seem self-evident: a) it is not possible to reconstruct the overall framework of the document (the sections pertaining to various sectors in education are disconnected); b) the defined scope of work attributed to various Ministry departments is even broader and more ambitious than that defined by the previous Ministry; c) not one of the listed activities/jobs defines any responsible implementing agency other than the Ministry itself, and the resources are not planned; d) all projects, initiatives and actions related to education with a source other than the Ministry are completely overlooked (there is no mention of the Institute for the Improvement of Education and the Institute for the Evaluation of Quality in Education, which, according to the "Umbrella 2 Law", should closely cooperate with the Ministry); e) if this is the strategy for the development/improvement of education, it is surprising that The National Council for Education - whose basic duty, according to "Umbrella 2 Law", is to develop policies in education - is barely mentioned in the document.

\section{Conclusions on the changes in 2001-05}

The first category of conclusions pertains to education policy itself in an unstable political environment. The reformists from the 2001-2003 period understood the importance of the political context very well: “The major precondition for the adequate functioning of the education system, and for the success of the changes aimed to improve education, is the very existence of a stable legal and political environment." (MES, 2004, p. 9). They also knew that there was no such stability at the time in Serbia; yet, for some strange reason, they decided to completely ignore this fact. They spent two and a half years of their threeyear mandate on "theorising" and construing their perfect education model, producing loads of "conceptions", "strategies", and "foundations". During these long two and a half years there were few concrete, practical actions and measures that were implemented and eventually became sustainable. Only during the last six months of their mandate did they start actually transferring some of their broad, general ideas into tangible results (passing the "Umbrella 1 Law", constituting certain independent professional institutions, creating school programmes/curricula). All of this, however, even if it could have been proven useful (which is highly doubtful), never had the time to take root, and was very 
easy to simply eradicate.

Besides the striking imbalance between long-term targets and practical actions, there were a number of other factors that caused the 2001-2003 reform to produce modest results:

- It was a top-down reform based on the Etic approach rather than Emic approach;

- $\quad$ Serious reforms require significant financial investments;

- The reform was not based on a solid analysis and assessment of the situation at the time in Serbian education (this analysis did exist, but the top-down approach simply ignored it, using it only sporadically);

- The problems and dilemmas faced in reality were never discussed in the policy and reform documents of the 2001-03 Ministry. Instead, these documents just presented general concepts, flaunting them during large convention-type gatherings, and simply assuming and demanding that they be accepted;

- Outlining the concept of the reform and its consequent implementation did not involve the existing national institutions, who wanted to participate autonomously in policy creation and decision making. Instead, the reformers arbitrarily and subjectively selected the experts and professionals who would implement the reforms;

- Over a three-year period, no independent national institution was created to participate in conceptualising and implementing the reforms;

- The reformers refused to accept initiatives from other stakeholders (the Serbian Lyceum/Gymnasium Association, for example, developed in detail its own concept of how to reform all college prep high schools, but the Ministry simply ignored its suggestions), and were very touchy about any kind of criticism and unable to develop any kind of communication with their critics;

- The reformers simply failed to implement many concrete measures under the conditions and within the given timeframe that was originally planned;

- In the period 2004-05, the new "Umbrella Law" annulled all of the structural changes in the education system introduced previously that had caused too much turbulence and confusion within the system;

- In May/June 2005, the Ministry of Education presented two important policy documents/strategies, but both texts have serious drawbacks.

In the Republic of Serbia, during the entire period between 2001 and 2005, regardless of the reforms introduced by the Ministry of Education, some 
initiatives, projects and actions important for improving the quality of education in Serbia began to be realised (The National Plan of Action for Children, The Poverty Reduction Strategy Paper, The Strategy for the Improvement of Education of the Roma Population, etc). Based on these changes, which took place in a politically unstable country during the period 2001-2005, two types of conclusions can be made:

- $\quad$ Regarding the relationship between education policy and politics: when education reforms are taking place within the context of political instability, the sustainability of these changes can only be ensured by creating reforms that rely not only on changes directly dependent on the education authorities but also on independent factors (e.g. independent professional institutions; individual schools that have commenced reforms; associations of teachers; university and research institutions that have started implementing reforms, etc;

- $\quad$ Besides the political instability during this period, some changes that enhance quality and equity in education did occur (the creation of a system for the professional development of teachers, the creation of institutions that conduct the assessment of student achievement, the beginnings of the creation of VET that is adapted to the economic situation).

In spite of all of the turbulence and inconsistencies, some sustainable changes that occurred in Serbia could serve as a basis for the improvement of the entire nation with regard to tackling and resolving some problems related to ensuring the quality of education. Below we summarise and present the possible contributions of the reform initiatives and changes implemented hitherto: - Improving access and equity. An important contribution to this goal could be the creation of the NPA and the LPA, the Poverty Reduction Strategy, the Strategy for the Improvement of Roma Education, etc.

- Improving the quality of education. Achieving this goal could be greatly assisted by the creation of the Centre for the Evaluation of Quality in Education (now the Institute for the Evaluation of Quality in Education) and the continuation of its work, such as the national assessment of student achievement and participation in international programmes for the assessment of student achievement. Furthermore, the work of the Centre for the Professional Development of Teachers and its in-service teacher training could contribute to the achievement of this goal; and also, the establishment of the "teacher career ladder" mechanisms already defined in legal documents. The quality of education could also be strongly supported by the preservation of highly serious and challenging academic 
programmes, and by the liberalisation of the school textbook market, on the condition that the already established standards for textbook quality are genuinely implemented.

- Improving enrolment in and quality of preschool education programmes. This will surely be improved by the introduction of the "zero" grade, if developmentally appropriate programmes for this grade are developed. Introducing the obligatory Preparatory Preschool Programme in 2007 for children aged 5.5-6 years is an important measure in achieving this goal.

- Young people and adult education and training. This goal will be greatly affected by the reconstruction and revitalisation of the entire VET education system.

\section{Looking forward: The Strategy of Education Develop- ment in Serbia to $2020+$}

The aim of the analyses in the present text is to show what the basic, conceptual problems and weaknesses were in education changes in Serbia in the period 2001-05. Some observers have thought that the main problem was the interruption in the changes with the arrival of the new political garniture after 2005, but we hope that it is obvious from our analyses that the main problems were actually: conceptual (the approach to changes) and procedural (how the innovations were introduced in the system). Primarily, it is the lack of following: a comprehensive theoretical approach; a reliance on the strengths of the system itself; a reliance on positive experiences in practice; a holistic approach to reforming the education system, resulting in the introduction of certain solutions with no consideration of their relationship to other measures and to other parts of the system; viewing education as part of wider social context, with links to other sectors in society; critical analyses of borrowed solutions and their appropriateness for our sociocultural context; a broad, transparent and consultative approach, with numerous different and relevant aspects, from professional circles to citizens' circles; taking into account reality, the real conditions for implementing noble ideas,etc.

One could say that the period 2005-2009 was a kind of "lull". The "third" wave of education changes in Serbia is characterised by the development of the Strategy of Education Development in Serbia to 2020+ (Ministry of Education and Science of Serbia, 2012). In August 2009, a new "Umbrella Law" was adopted, and in July 2011 the Parliament adopted certain changes to this law: Amendments and Additions to the Law on the Foundations of the Education System in Serbia. However, the main precursor to the Strategy was the document Education in Serbia: How to achieve better results. Trends in the development and upgrading 
of the quality of preschool, primary, general secondary and art education and upbringing 2010-2020 (2011, hereinafter Trends). The document Trends is a strategic document focused on pre-university education, and it is complementary to the Strategy of Education Development in Serbia (SDES). The SDES is a proposal by an expert group that has passed through broad professional and public consultative processes and entered in official procedure for acceptance. In addition, this wave of reform tries to answer serious questions regarding quality and equity in education. In Trends and the SDES there are four main parameters: access, quality, relevance and efficacy of the system, but the key criterion is quality, and no measure can be accepted if it jeopardises quality.

In comparison with the changes in the period 2001-05, the SDES is different both in terms of conception and procedure of preparation, as well as in some concrete solutions. Below are some key specificities of the SDES:

- It incorporates a comprehensive and detailed analysis of all levels of the education system. In the public hearings on the proposal of the SDES, particular emphasis was placed on its representing a very good and precise picture of the state of the system. Unlike the reforms of 2001-05, in the SDES a serious assessment of current issues in Serbian education has been created as a basis for finding solutions and for finding resources within the system for its improvement (SED, 2012);

- In the preparation of the SDES, three approaches were combined: research findings, relevant national and international documents (analyses, trends, assessments, reports, etc) and the rich practical experience with schools and teachers in Serbia;

- The SDES recognises the strong sides of education in Serbia, and the changes are based on these sides (Emic approach) as well as on all possible supports outside the system;

- The SDES is a holistic approach in two senses: firstly, it treats education in close connection with other sectors (it is not a reform dealing with itself rather than with the relationship of education to other important sectors of the society); and, secondly, the changes cover all education levels from preschool to lifelong learning. This further means that all of the proposed solutions must be compliant and compatible with one another, forming a logically consistent system;

- Particular solutions in the SDES are developed from the mission of each education level (preschool, primary, secondary, tertiary, doctorial studies and LLL). The solutions were analysed in relation to one another, so together they constitute a logical whole;

- At each level in the SDES, the strategic measures for fulfilling expected 
outcomes have been developed in such way that it is easy to transfer them to an Action Plan for their realisation. Each possible partner (institutions, organisations, particular individuals, etc.) related to Serbian education and to the planned solutions was taken into account and is expected to take responsibility for and contribute to improvement of the system;

- The SDES is a realistic approach, i.e., the whole construction is based on preconditions that can be fulfilled in the Serbian reality by 2020. Furthermore, there is a financial dimension, which is a necessary support for education changes;

- The proposal of the SDES has been discussed within rich consultative processes involving numerous different stakeholders (the draft of each group was discussed by the members of consultative groups, by opponents and by international experts), and when it was revised on the basis of suggestions and comments received it was presented to the public all over Serbia in several ways: formal public presentations in different towns in Serbia; on the website of the MES; in panels, round tables, discussion groups in various institutions and organisations; and at conferences and meetings related to education;

- $\quad$ The SDES represents an endeavour to move education in Serbia in the right direction and enable it to go forward. In this sense, the long-term targets (the mission of the system) are translated into practical actions in future years or phases are created.

Looking back, we see that in the last decade there have been constant attempts to introduce the necessary innovation in education in Serbia (e.g., standards of student achievement, standards for the evaluation of teachers, standards of textbook quality, the professional promotion of teachers, etc.). This process is very difficult for many reasons, including: the lack of political support; the inertia of the education system; the negative influence of sociocultural and economic variables; some of the measures are not well executed professionally (e.g., standards of textbook quality); sometimes mechanisms for the implementation of measures are not ensured (e.g., the professional promotion of teachers), etc.

The SDES has provided a comprehensive and realistic way to improve education. Now the SDES is in the procedure for acceptance by the government. However, the problem of SDES implementation is, of course, open and uncertain, and depends on the political will of the future Serbian government to accept education as a one of the developmental potentials of Serbia and to turn it into concrete measures in state policy. 


\section{Acknowledgements}

We would like to thank UNESCO, Division of Educational Policy Analysis and Educational Evaluation and Prof. Vinayagum Chinapah for the initiative for this analysis, which is part of broader research on monitoring and evaluating progress in the implementation of the goals of Education for All in Serbia. Also, we are grateful to the Ministry of Education and Science of Serbia, as the analyses have been realised within the framework of the project Identification, measurement and development of cognitive and emotional competencies that are important for a society oriented toward European integration (No. 179018).

\section{References}

Education in Serbia: How to reach better results. Trends in development and upgrading of the quality of preschool, primary, general secondary and art education and upbringing 2010-2020 (2011). Belgrade: The National Council for Education, Belgrade.

Ivić, I. (2001). L'éducation dans les pays de l'est et du sud -est de l'Europe : destruction, reconstruction, réforme? Pensée, 326(Avril/juin), 87-94.

Ivić, I. (2005). Monitoring \& Evaluation of EFA Implementation. Elaborate for Division of Educational Policy Analysis and Educational Evaluation, UNESCO.

MES (2002a). Kvalitativno obrazovanje za sve - put ka razvijenom drustvu (Quality Education for All - A Path to a Developed Society). Belgrade: Ministry of Education and Sport.

MES (2002b). Reforma srednjeg strucnog obrazovanja: od razgovora do realizacije (Reform of the VET: From Conversation to Implementation). Belgrade: Ministry of Education and Sport. MES (2003a). Katalog programa strucnog usavrsavanja zaposlenih u obrazovanju (Catalogue of InService Training for Employees in Education). Belgrade: Ministry of Education and Sport. MES (2003b). Zakon o osnovama sistema obrazovanja i vaspitanja (The Law on the Foundations of the Education System). Belgrade: Ministry of Education and Sport.

MES (2004). Kvalitetno obrazovanje za sve: Izazovi reforme obrazovanja u Srbiji (Quality Education for All: The Challenges of Education Reform in Serbia). Belgrade: Ministry of Education and Sport. MES (2004a). Zakon o izmenama i dopunama Zakona o osnovama vaspitanja iobrazovanja (Amendments and Additions to the Law on the Foundations of the Education System). Belgrade: Ministry of Education and Sport.

MES (2005). Strategija Ministarstva prosvete i sporta za period 2005-2010 godine (The Strategy of the Ministry of Education and Sport for the 2005-2010 Period).

Ministry of Finance (2005). Memorandum o budzetu, o ekonomskoj i fiskalnoj politici za 20o6.godinu sa projekcijama za 2007. i 2008.godinu (Memorandum on Budget and Economic and Fiscal Policy for 2006, with Projections for 2007 and 2008).

National Action Plan (2004). Republic of Serbia: Plan of Action for Children. Belgrade: Government of Serbia. 
Pešikan, A. (Ed.) (2012, in press). Analiza osnovnih resursa u preduniverzitetskom obrazovanju u Srbiji. Beograd: Filozofski fakultet.

Pešikan, A., Antić, S., \& Marinković, S. (2010a). Koncepcija stručnog usavršavanja nastavnika u Srbiji: između proklamovanog i skrivenog modela. Nastava i vaspitanje, (2), 278-297

Pešikan, A., Antić, S., \& Marinković, S. (2010b). Koncepciija stručnog usavršavanja nastavnika u Srbiji: koliko smo daleko od efikasnog modela. Nastava $i$ vaspitanje, (3), 471-483

Pešikan, A., \& Ivić, I. (2009). Obrazovanjem protiv siromaštva: Analiza uticaja uvođenja pripremnog predškolskog programa u Srbiji. Vlada Republike Srbije, Tim potpredsednika Vlade za implementaciju SSS i Ministrastvo prosvete RS.

Poverty Reduction Strategy in Serbia (2003). Belgrade: Government of the Republic of Serbia.

Radó, P., \& Lazetić, P. (2010). Rapid assessment of the implementation of inclusive education in Serbia. Belgrade: UNICEF

Radó, P. (2009). Improving the inclusive capacity of schools in Serbia, Expert study for the DILS

Program Serbia. Belgrade.

Strategy of Education Development in Serbia to $2020+$ (2012). Belgrade: Ministry of Education and Science of Serbia.

Strategy of the Ministry of Education and Sport for the Period from 2005 to 2010 (2005). Belgrade:

Ministry of Education and Sport.

The National Strategy for Education from 2005 to 2010 (2005). Belgrade: Ministry of Education and Sport.

UNICEF (2001). Comprehensive Analysis of Primary Education in the Federal Republic of Yugoslavia. Belgrade: UNICEF.

UNICEF (2004). Evaluative Review of Active Learning in Serbia and Montenegro. Belgrade: UNICEF.

Zakon o osnovama sistema obrazovanja i vspitanja u Republici Srbiji. Vlada Republike Srbije, Službeni glasnik RS, br. 72/o9.

Zakon o izmenama i dopunama Zakona o osnovama sistema obrazovanja i vaspitanja. Službeni glasnik RS, br. 52/2011. 


\section{Biographical note}

Ivan Ivić, Professor, is leading developmental psychologist and educational expert in Serbia and ex-Yugoslavia but also in the international organizations (OECD expert for education; high level expert in CERI/OECD; OMEP; UNICEF). He was the coordinator of the major project on the evaluation of the education system in FR Yugoslavia, UNICEF, Belgrade); consultant of the Georgian Ministry of Education (1998); and member of UNESCO International Peer Group Review in Educational Evaluation. He was the minister of education in ex Yugoslavia (1991). Now professor Ivić is the coordinator and main author of the Strategy of education development in Serbia $2020+$.

Ana Pešikan is Associate Professor at the Faculty of Philosophy, Department of Psychology at the University of Belgrade, Serbia. Her professional interests are educational and developmental psychology. The focus of her work is on the active learning methodology, the construction and analysis of the textbook and teaching/learning history in school. She is national and UNICEF expert for education. She was the minister of science in Serbian Government (2007-2008). She is one of the founder and member of Education Forum, think-tank organization for educational issues and one of the authors of the Strategy of education development in Serbia 2020+. 